\title{
Suitability Between Ocenography and Seaweed (Eucheuma cottonii) Cultivation Potential in Tidung Island with Geographic Information System (GIS)
}

\author{
Regi Zaky Utama ${ }^{1}$, Tuty Handayani ${ }^{2}$ \\ ${ }^{1}$ Departement of Geography, Faculty Mathematics \& Natural Science, Univesitas Indonesia, Depok - Indonesia \\ ${ }^{2}$ Departement of Geography, Faculty Mathematics \& Natural Science, Univesitas Indonesia, Depok - Indonesia
}

\begin{abstract}
The Tidung Island in Kepulauan Seribu District is a tourist destination for both domestic and foreign tourists. However, not all residents of Tidung Island work in the tourism sector. Some work as fishermen. In 2016, local governments developed seaweed cultivation (Eucheuma cottonii) which made some residents switched jobs to seaweed farmers. This study aims to determine which areas are oseanographically appropriate and have potential as a seaweed cultivation development area. The research method use variables of oceanography in the form of substrate type, protected, temperature, depth, current speed, salinity, and $\mathrm{pH}$. The cultivation variable consists of labor, technology, and management. To determine the direction of development, tourism variables which being used consist of distance from tourist sites and the number of supporting facilities. The analysis uses Geographic Information System (GIS) technique and scoring method. The results show in the northern Tidung Island waters are suitable for seaweed cultivation from the point of view of oceanography. However, the development potential is only in U2 segment, which is support by high production quantities, long distance from tourism object, and low number of accommodation makes it potentially to be developed area.
\end{abstract}

Keywords: Tidung Island; Development Potential; Seaweed Cultivation; Geographic Information System.

\section{Introduction}

Indonesia is an archipelago geographically with two thirds of the vast ocean bigger than the Mainland. This can be seen by the existence of the shoreline in nearly every island in Indonesia $( \pm 81,000 \mathrm{~km})$ which made Indonesia ranks second after Canada as country that has the longest coastline in the world [1]. With the larger sea area, then Indonesia has potential in the utilization of marine resources.

Seaweed is one of the commodities of marine resources have a great potential to be developed, has a high economic value, easily cultivated and have low production costs [2]. Seaweed and its derivatives have many uses. Historically, seaweed was commonly used as fertiliser and food for animals or people, particularly during food shortages. In modern times, it has many applications in the cosmetic, food processing, biomedical, pharmaceutical and printing industries and as a feedstock for biofuels and anaerobic digesters [3].

Tidung Island, located in Kepulauan Seribu Selatan, is a very busy tourist destination [4]. Tidung Island can be utilized not only from the tourism sector, but can be utilized from water resource sector. With the development of tourism in Tidung Island surely have an effect on the development of the cultivation of seaweed which already existed before. The development of tourism on an area can cause some environmental problems, one of which is the issue of waste resulting from tourism activities [5].

To review the potential development of the potential of seaweed cultivation particularly in Tidung Island, it must be held that the research of variable oceanographic, cultivation, and tourism. This research aims to analyze the suitability and determine development potential of seaweed cultivation. If seaweed on Tidung Island can be develop, than the possibility of storing carbon on sea surface will be higher.

\section{Material and Methods}

\subsection{Study Area}

This Study was conducted in Tidung Island. Tidung Island is located at position $5^{\circ} 79^{\prime}-5^{\circ} 80^{\prime}$ south latitute and $106^{\circ} 47^{\prime}-106^{\circ} 51^{\prime}$ west longitude. This study focused on the coastal Tidung Island.

\subsection{Variable}

*Corresponding author: tuty.handayani@gmail.com 
Table 1. Study Variable

\begin{tabular}{|l|l|l|}
\hline No & \multicolumn{1}{|c|}{ Variable } & \multicolumn{1}{c|}{ Description } \\
\hline 1 & Oceanography & $\begin{array}{l}\text { Oceanographic parameters of waters } \\
\text { that is the substrate type, protection, } \\
\text { temperature, depth, current velocity, } \\
\mathrm{pH}, \text { and salinity. }\end{array}$ \\
\hline 2 & Cultivation & $\begin{array}{l}\text { Parameters of cultivation i.e., 1abor, } \\
\text { technology, and management (capital, } \\
\text { marketing, and productivity). }\end{array}$ \\
\hline 3 & Tourism & $\begin{array}{l}\text { Parameters of tourism as a barrier that } \\
\text { is the distance of the sights with the } \\
\text { location of the cultivation and the } \\
\text { number of accommodation for the } \\
\text { development of the cultivation of } \\
\text { seaweed. }\end{array}$ \\
\hline
\end{tabular}

\subsection{Processing Data}

In this study using GIS technology in determining the suitability and the potential development of the cultivation of seaweed. GIS is a system consisting of hardware, software, data, human (brainware), organizations and institutions that are used to collect, store, analyze, and disseminate information related to the Earth's surface [6]. GIS is utilized as a tools that are reliable in support in programs with spatial data and information.

In this case the weighting based on Oceanography for seaweed cultivation [7] as follows :

Table 2. Weighting Oceanography for the Suitability Area

\begin{tabular}{|c|c|c|c|}
\hline No & Parameters & Value & Multiplier \\
\hline 1 & $\begin{array}{l}\text { Substrate Type } \\
\text { coral } \\
\text { sand } \\
\text { mud }\end{array}$ & $\begin{array}{l}5 \\
3 \\
0\end{array}$ & 3 \\
\hline 2 & $\begin{array}{l}\text { Protection } \\
\text { protected } \\
\text { not protected }\end{array}$ & $\begin{array}{l}5 \\
3\end{array}$ & 2 \\
\hline 3 & $\begin{array}{l}\text { Current Speed } \\
<0.20 \\
0.20-0.30 \\
0.31-0.40 \\
>0.40\end{array}$ & $\begin{array}{l}1 \\
5 \\
3 \\
1 \\
1\end{array}$ & 3 \\
\hline 4 & $\begin{array}{l}\text { Salinity } \\
<28960 \\
28-31960 \\
32-34960 \\
>34960\end{array}$ & $\begin{array}{l}0 \\
5 \\
3 \\
0 \\
0\end{array}$ & 3 \\
\hline 5 & $\begin{array}{l}\text { Depth } \\
<30 \mathrm{~cm} \\
30-60 \mathrm{~cm} \\
>60 \mathrm{~cm}\end{array}$ & $\begin{array}{l}1 \\
1 \\
3 \\
3\end{array}$ & 2 \\
\hline 6 & $\begin{array}{l}\text { Temperature } \\
<266^{\circ} \mathrm{C} \\
26-30^{\circ} \mathrm{C} \\
31-35^{\circ} \mathrm{C} \\
>35^{\circ} \mathrm{C}\end{array}$ & $\begin{array}{l}0 \\
5 \\
3 \\
0 \\
0\end{array}$ & 2 \\
\hline 7 & $\begin{array}{l}\mathrm{pH} \\
<7.5 \\
7.5-8.5 \\
8.5-9 \\
>9\end{array}$ & $\begin{array}{l}0 \\
5 \\
3 \\
0 \\
0\end{array}$ & 2 \\
\hline
\end{tabular}

Oceanographic parameters of the results of weighting to obtain the results of the suitability area for the cultivation of seaweed. Results weighting is divided into 4 classifications [8].

Table 3. Classification Suitability Area

\begin{tabular}{|l|l|}
\hline \multicolumn{1}{|c|}{ Class } & \multicolumn{1}{c|}{ Score } \\
\hline Very Suitable & $86-100$ \\
\hline Suitable & $76-85$ \\
\hline Less Suitable & $66-75$ \\
\hline Not Suitable & $<65$ \\
\hline
\end{tabular}

Create a classification based on cultivation, and tourism for development potential area for cultivation of seaweed which is obtained from the results of the modification $[9,10]$ and the classification of areas based on the weights for each parameter.
Table 4. Modification Weighting Potential Area

\begin{tabular}{|c|c|c|c|}
\hline No & Parameters & Value & Multiplier \\
\hline 1 & $\begin{array}{l}\text { Labor } \\
\text { high } \\
\text { medium } \\
\text { low }\end{array}$ & & 2 \\
\hline 2 & $\begin{array}{l}\text { Method } \\
\text { bottom monoline } \\
\text { floating bamboo } \\
\text { long line }\end{array}$ & $\begin{array}{l}1 \\
5 \\
3\end{array}$ & 2 \\
\hline 3 & $\begin{array}{l}\text { Capital } \\
\text { high }(>R \text { R.2 M) } \\
\text { medium }(R p .1-2 M) \\
\text { low }(<R \text { p.1 M })\end{array}$ & $\begin{array}{l}5 \\
3 \\
2\end{array}$ & 2 \\
\hline 4 & $\begin{array}{l}\text { Marketing } \\
\text { direct } \\
\text { Indirect }\end{array}$ & $\begin{array}{l}5 \\
3\end{array}$ & 2 \\
\hline 5 & $\begin{array}{l}\text { Productivity } \\
\text { high }\left(>300 \mathrm{Kg} / 500 \mathrm{~m}^{2}\right) \\
\text { medium }\left(150-300 \mathrm{~kg}^{2} / 500 \mathrm{~m}^{2}\right) \\
\text { low }\left(<150 \mathrm{~kg} / 500 \mathrm{~m}^{2}\right)\end{array}$ & $\begin{array}{l}5 \\
3 \\
1\end{array}$ & 4 \\
\hline 6 & $\begin{array}{l}\text { Tourism Object Distance } \\
\text { near }(500 \mathrm{~m}) \\
\text { medium }(500-1000 \mathrm{~m}) \\
\text { far }(>1000 \mathrm{~m})\end{array}$ & $\begin{array}{l}1 \\
3 \\
5\end{array}$ & 4 \\
\hline 7 & $\begin{array}{l}\text { Number Tourist } \\
\text { Accommodation } \\
\text { high }(>20) \\
\text { medium }(10-20) \\
\text { low }(<10)\end{array}$ & $\begin{array}{l}1 \\
3 \\
5\end{array}$ & 3 \\
\hline
\end{tabular}

Each parameter value is counted it weigh then added so retrieved 4 class

Table 5. Class potential development with weighting

\begin{tabular}{|l|l|}
\hline \multicolumn{1}{|c|}{ Class } & \multicolumn{1}{c|}{ Score } \\
\hline High Potential & $80-100$ \\
\hline Moderate Potential & $60-79$ \\
\hline Low Potential & $40-59$ \\
\hline Not Potential & -40 \\
\hline
\end{tabular}

\subsection{Data Analysis}

With spatial analysis (overlay) will be obtained in the form of a map of the area where the entry into the territory of high potential, moderate potential, low potential, and not potential. With descriptive analysis also gives description and also explanation based on field condition and data presented in table

\section{Result}

\subsection{Suitable Area Between Oceanography}

\subsubsection{Substrate Type}

Substrate type on the entire coast of Tidung Island are surrounded by sand. On the north coast is dominated by sand due to the influence of protection that makes the presence of sand in the segment.

This occurs because in Tidung Island does not have fringing reef so that all waters have a substrate type of sand. This can facilitate seaweed farmers to stick a peg for seaweed cultivation.

\subsubsection{Protection}

Protection depends on the shape of the shore and the presence of a waves barrier. On the southern coast there is protection made by humans to prevent direct influence when large waves occur. On the northern shore a natural protection is made that protects the effects of large 
waves. Most of the coastal areas of Tidung Island have protection, unless in the U1, S1, U4 and S4 segments.

\subsubsection{Current Speed}

The current speed on the north coast of Tidung Island is relatively the same because in the north coast it has protection. On the south coast of Tidung island has a larger current speed, due to the direction of the current speed is coming from the northern coast. In north coast has $0.20-0.30 \mathrm{~m} / \mathrm{s}$, and in south coast has $0.31-0.40 \mathrm{~m} / \mathrm{s}$.

\subsubsection{Depth}

The depth of waters in Tidung Island average ranges from $0-105 \mathrm{~cm}$. The depth of the sea water is getting higher when approaching the shore of the sea, while getting closer to the shoreline the depth is lower. This is caused by the movement of sea water. The more towards the edge, the bigger the waves which cause the movement of water to make the substrate of the bottom of the water go deeper.

The depth of sea water is getting higher as it approaches the seafront, and if it approaches the coastline, the depth is lower. On the north coast is dominated by a depth of $<60 \mathrm{~cm}$, and on the south coast is dominated by a depth of $>60 \mathrm{~cm}$.

\section{$3.1 .5 \mathrm{pH}$}

The $\mathrm{pH}$ of waters in Tidung Island dominated with pH 7.5 - 8.5. There are only differences in the north and south coasts of the eastern part of Tidung Island that belong to the waters of the $\mathrm{U} 4$ and $\mathrm{S} 4$ segments. Across the coastal areas of $\mathrm{U} 1, \mathrm{U} 2, \mathrm{U} 3, \mathrm{~S} 1, \mathrm{~S} 2$, and S3 segments have a value of 7.5 to 8.5 . The $\mathrm{pH}$ of the waters on Tidung Island is very supportive for seaweed growth.

\subsubsection{Temperature}

The temperature of Tidung Island waters is dominated with temperatures of $31-35^{\circ} \mathrm{C}$. Only on the north coast in the $\mathrm{U} 2$ and $\mathrm{U} 3$ segments has a temperature of $26-30{ }^{\circ} \mathrm{C}$. In other coastal locations in the segment $\mathrm{U} 1, \mathrm{U} 4, \mathrm{~S} 1, \mathrm{~S} 2, \mathrm{~S} 3$, and S4 has a temperature of $31-35$ ${ }^{\circ} \mathrm{C}$. Then, the entire coastal area Tidung Island that can support for the growth of seaweed.

\subsubsection{Salinity}

The average salinity on the coast of Tidung Islang is $32 \%$. Water salinity in Tidung Island is dominated by 32 - $34 \%$. On the north coast of Tidung Island has a value of $28-31 \%$ in the segment U1, U2, and U3. While in the south and north east of the segment U4, S1, S2, and S3 has a value of $32-34 \%$. This shows that waters salinity in all areas supports for seaweed growth, but more on segment U1, U2, and U3 which have value $28-31 \%$.

\subsubsection{Suitability Area of Seaweed Cultivation}

Based on the weighting of parameters for oceanographic variables and spatial data management, it was found that the suitability area in Tidung Island. Suitability area in Tidung Island consist of suitable, less suitable, and not suitable.

The suitable areas are located on the north coast on Tidung Island in the U2 and U3 segments. Less suitable areas are also found in some northern part on U2 and U4 segments. While the areas that is not suitable in the southern coastal in S1, S2, S3, and S4 segment.

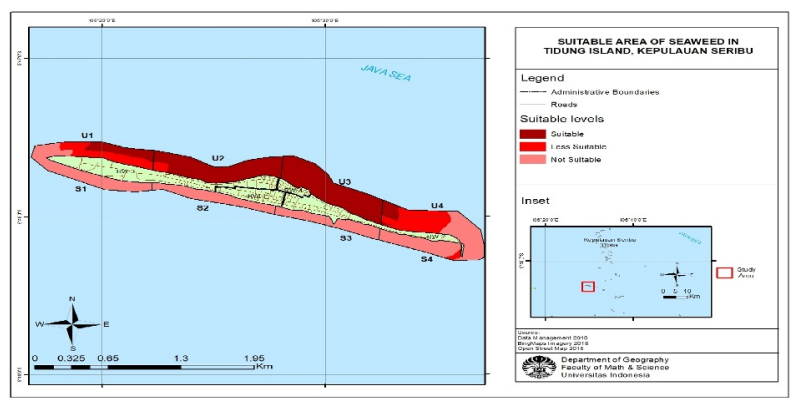

Fig 2. Suitable Area of Seaweed

\subsection{Potential Area of Seaweed Cultivation}

\subsubsection{Labor}

Seaweed cultivation activity is one of the livelihood for the people who live in Tidung Island. The seaweed farmers are mostly residents who live on the beach.

From the survey results identified the number of farmers in the U2 segment is the region with the largest number of seaweed farmers totaling 9 people. This is due to natural factors that support the waters of Tidung Island, especially the northern coast that has the protection that is made naturally.

\subsubsection{Technology}

Technology is a tool used in seaweed cultivation. Technology is not only dependent on high technology, but also can depend on simple tools. In this case the technology in question is the method of seaweed cultivation.

In Tidung island there is only 1 method used in cultivating seaweed is bottom monoline method. In all the locations in Tidung Island use that because in preparation is easier and cheaper.

\subsubsection{Capital}

The capital used by seaweed farmers to buy seeds and cultivation preparation is their own capital. There is no capital aid to help the development of seaweed cultivation in Tidung Island from government or private parties.

Capital needed to cultivate seaweed about $\mathrm{Rp}$. 500.000 - Rp. 2.500.0000 depending on the number of 
seedlings you want to use. Location that has the largest capital is in the U2 segment of Rp. 2.050.000 and the lowest is in the U1 segment that is Rp. 750.000 with a width of about $500 \mathrm{~m}^{2}$.

\subsubsection{Marketing}

Seaweed prices tend to be stable in Tidung Island. In this case, the selling price is divided into between wet seaweed and dried seaweed. Selling price of wet seaweed on Tidung Island around Rp. 5.000 / Kg, while the selling price of dried seaweed is sold around $\mathrm{Rp}$. 11.000 - Rp. $13.000 / \mathrm{Kg}$. The selling price for dried seaweed in other regions averages $\mathrm{Rp} .6,500 / \mathrm{Kg}$ for dried seaweed [11].

Marketing of seaweed throughout Tidung Island directly sold to the collectors on Tidung Island. Seaweed collectors in Tidung island only have 1 person, it makes the selling price of seaweed relatively flat for sale price.

\subsubsection{Productivity}

Productivity of seaweed in Tidung Island ranges from 80 to $305 \mathrm{Kg} / 500 \mathrm{~m}^{2}$. Most of the seaweed farmers in Tidung Island can carry out seaweed cultivation throughout the year, harvesting up to 5-7 times a year. In productivity using the farming equation, namely :

$$
\text { Farming Productivity }=\frac{\text { Total Production }(\mathrm{Kg})}{\text { Area }\left(\mathrm{m}^{2}\right)}
$$

The highest production rate is in the U2 segment, which is around $305 \mathrm{~kg} / 500 \mathrm{~m}^{2}$. The lowest seaweed production is in the $\mathrm{U} 1$ and $\mathrm{U} 4$ segments with an average production of $<150 \mathrm{Kg} / 500 \mathrm{~m}^{2}$.

\subsubsection{Distance of Tourism Object}

Tidung Island is famous for nature tourism which is visited by many tourists. Tourist objects in Tidung Island is located in the East of Tidung Island, namely Jembatan Cinta. It can disturbs the life of seaweed in Tidung Island, so it is advisable not to cultivate seaweed near from the location.

Distance of tourism object with the location of waters in nearby Tidung Island about $<1 \mathrm{Km}$ is in segment U4. While on the U3 segment is a moderate distance of $1-2 \mathrm{Km}$ of tourist object. In the segment U1 and $\mathrm{U} 2$ is far away because $>2 \mathrm{Km}$ from tourist object in the east of Tidung Island.

\subsubsection{Number of Accomodation}

Accommodation is also a place to stay for tourists while traveling on Tidung Island. There are a variety of lodging on Tidung Island which is homestay, villa, and hotel.

The rapid progress of tourism can also be characterized by the increasing number of tourist facilities buildings [12]. The highest number of lodging in the U3 segment totally is 33 , and the lowest number of lodging is in the U1 and U2 segments totally is 9. It happens because in the $\mathrm{U} 3$ and $\mathrm{U} 4$ segments close to the tourist object.

\subsubsection{Potential of Seaweed Cultivation Development}

Potential development of seaweed cultivation in Tidung Island is divided into 4 segments on the north coast in the segment U1, U2, U3, and U4. In terms of cultivation, there are several factors that make reference are natural factors, labor factors, technological factors, and management factors.
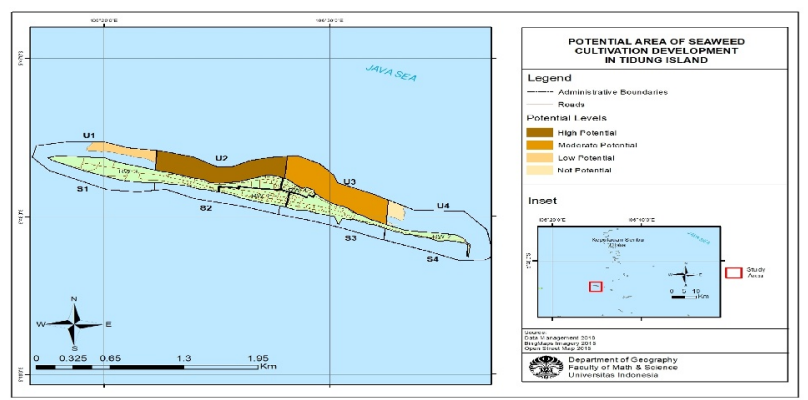

Fig 3. Potential Area of Seaweed Cultivation

\subsubsection{Potential Area in U1 Segment}

Table 6. Potential Area in U1 Segment

\begin{tabular}{|l|l|l|}
\hline No & Indicators & Result \\
\hline 1 & Labor & Low \\
\hline 2 & Capital & Low \\
\hline 3 & Productivity & Low \\
\hline 4 & Distance Tourism Object & Far \\
\hline 5 & Number of Lodging & Low \\
\hline
\end{tabular}

In the coastal area of U1 segment there is 7 ha of suitable area for seaweed cultivation. In this segment has a low labor, cultivation method using single monoline, low capital for cultivation, marketing for seaweed is indirect with collector, low seaweed production, tourism distance is far to cultivation location, and the low number of lodging makes this segment is to a low potential area.

\subsubsection{Potential Areas in U2 Segment}

Table 7. Potential Area in U2 Segment

\begin{tabular}{|l|l|l|}
\hline No & Indicators & Result \\
\hline 1 & Labor & High \\
\hline 2 & Capital & High \\
\hline 3 & Productivity & High \\
\hline 4 & Distance Tourism Object & Far \\
\hline 5 & Number of Lodging & Low \\
\hline
\end{tabular}

In the coastal area of the U2 segment there is an area of 25 ha of suitable area for seaweed cultivation. In this segment has a high labor, cultivation methods using single monoline, high capital for cultivation, marketing for seaweed is indirect with collector, high seaweed production, tourism distance is far to cultivation 
location, and the low number of lodging makes this segment to be a high potential area.

\subsubsection{Potential Areas in U3 Segment}

Table 8. Potential Area in U3 Segment

\begin{tabular}{|l|l|l|}
\hline No & Indicators & Result \\
\hline 1 & Labor & Medium \\
\hline 2 & Capital & Medium \\
\hline 3 & Productivity & Medium \\
\hline 4 & Distance Tourism Object & Medium \\
\hline 5 & Number of Lodging & High \\
\hline
\end{tabular}

In the coastal areas of the U3 segment there is an area of 30 ha of areas suitable for seaweed cultivation. In this segment has a medium labor, cultivation methods using bottom monoline, medium capital for cultivation, marketing for seaweed is indirect with collector, medium seaweed production, tourism distance is medium to cultivation location, and high number of lodging makes this segment to be a moderate potential area.

\subsubsection{Potential Areas in U4 Segment}

Table 9. Potential Area in U4 Segment

\begin{tabular}{|l|l|l|}
\hline No & Indicators & Result \\
\hline 1 & Labor & Low \\
\hline 2 & Capital & Low \\
\hline 3 & Production & Low \\
\hline 4 & Distance Tourigm Object & Near \\
\hline 5 & Number of Lodging & Medium \\
\hline
\end{tabular}

In the coastal areas of the U4 segment there is an area 3 ha of area suitable for seaweed cultivation. In this segment has low labor, cultivation methods using bottom monoline, low cultivation capital for cultivation, marketing for seaweed is indirect with collector, low seaweed production, tourism distance to near to cultivation location, and medium number of lodging makes this segment to be to a not potential area.

\section{Conclusion}

Based on oceanographic variables with substrate type, protection, current speed, salinity, depth, temperature, and $\mathrm{pH}$ on the north coast of Tidung island on U1, U2, U3 and U4 segments are suitable areas for seaweed cultivation with an area of $65 \mathrm{Ha}$. On the southern coast of Tidung Island on S1, S2, S3, and S4 segments are not suitable areas.

Potential areas of seaweed cultivation development based on cultivation and tourism object has a high area potential to be developed are in the U2 segment. The most influential for the development of seaweed cultivation is the high production, tourism distance is far to cultivation location, and the low number of lodging makes the area potentially to be developed.

\section{Acknowledgements}

The research work reported in this paper was funded by PITTA Grant No.
2326/UN2.R3.1/HKP.05.00/2018 Universitas Indonesia (UI).

Thanks to directorate Research and Community Service Universitas Indonesia also my advisor in Hibah Pitta group.

\section{References}

1. I. Hardiana, Trixie. Potensi Indonesia Sebagai Negara Maritim. (Sekertariat Kabinet Republik Indonesia, 2014)

2. Yulius, Ardiansyah, M. Ramdhan, A. Heriati, H. Salim, D. Purbani, S. Amri, T. Arifin. Kesesuaian Kawasan Budi Daya Rumput Laut di Teluk Saleh, Kabupaten Sumbawa, Nusa Tenggara Barat. J. Segara, E 12, 11 (2016)

3. C. Rolin, R. Inkster, J. Laing, J. Hedges, L. McEvoy. Seaweed Cultivation Manual (NAF Marine Center, University of the Highlands and Island, 2016)

4. T. Handayani, E. Kartikoputro, A.H. Suparjo. Youth Education in Self-Preparing as Marine Ecotourism Guide in Kepulauan Seribu. J. Advances in Social Science, Education, and Humanities Research E 79, 329 (2017)

5. A. Dewi, S. Saraswati. 2016. Kajian Pengembangan Usaha Budidaya Rumput Laut Di Pantai Kukuh, Badung, Provinsi Bali. J. Mar. Aquat. Sci 2, E 1, 1 (2016)

6. N. Chrisman. 1997. Exploring Geographic Information System. (John Willey \& Sons, Inc, 1997)

7. A. Kusumawardhani. Wilayah Intensitas Budidaya Rumput Laut di Pantai Karst Kabupaten Gunungkidul. (Universitas Indonesia, 2008)

8. M. Cornelia. Prosedur dan Spesifikasi Teknis Analisis Kesesuaian Budidaya Rumput Laut. (Pusat Survey Sumberdaya Alam Laut Bakosurtanal, 2005)

9. T. Wijayanto, M. Hendri, R. Arayawati. Studi Pertumbuhan Rumput Laut Euchema Chottonii dengan Berbagai Metode Penanaman yang berbeda di Perairan Kalianda, Lampung Selatan. J. Maspari E 3, 51 (2011).

10. H. Akbar. Analisis Kesesuaian Lokasi untuk Budidaya Rumput Laut di Kabupaten Sumbawa Barat. (Intitut Pertanian Bogor, 2014)

11. S.K. Hamid. Analisis Efisiensi Pemasaran Rumput Laut (Eucheuma cottonii) Di Kota Tual Provinsi Maluku. J. Ilmiah Agribisnis dan Perikanan E 5, 57 (2012)

12. I. Sugita. Dampak Perkembangan Pariwisata terhadap Keberlanjutan Usaha Tani Rumput Laut di Desa Kutuh, Kuta Selatan Kabupaten Badung (Universitas Udayana, 2015) 